\title{
Kontestasi antar orang asli Papua terhadap hak pertuanan di Kaimana
}

\section{Dispute between native Papuans to the customary right in Kaimana}

\author{
Cahyo Pamungkas \\ Pusat Penelitian Sumberdaya Regional (PSDR), Lembaga Ilmu Pengetahuan Indonesia (LIPI) \\ E-mail: cahyopamungkas_lipi@yahoo.com
}

\begin{abstract}
This article is addressed to describe the social relations within the Papuan ethnic groups and between Papua native and migrants concerning some customary rights in Kaimana district. This research describes the struggle of inland and beach tribes in fighting for customary rights of land in Kaimana. Moreover, it captures the respond of migrants in dealing with the customary right. This study shows the recognition of the the eldest ethnic in Kaimana is a strategy and discourse constructed by Papua ethnic groups that have felt marginalized while migrants have taken their resources. This right could be understood as the need for recognition of Papua ethnic groups. The most important issue is not who the native of Kaimana is, but what the proper ways to give recognition to Papua ethnic groups which had been left behind in development are. The relation between the Papua natives and migrants in Kaimana is not complicated as the migrants have no privileges in the political contestation. However, these relationship are affected by the differences in religious affiliations. The Muslim Papua ethnic groups generally have a closer relationship with the Muslim migrants. The analytical framework of this study using the theoretical framework of identity and ethnicity to look at the issue. Does the definition of identity and ethnicity according to sociological theories are still relevant to understanding the issue of claims of ethnic identity in the city of Kaimana.
\end{abstract}

Keywords: contestation of identity, Kaimana tribes, inland tribes, customary land, and customary rights

\begin{abstract}
Abstrak
Artikel ini bertujuan menjelaskan relasi sosial antar orang asli Papua, dan antara orang asli Papua dengan pendatang dari luar Papua terkait dengan hak pertuanan atas tanah di Kota Kaimana. Pertanyaan yang ingin dijawab dalam studi ini adalah bagaimanakah kontestasi klaim terhadap hak pertuanan di Kota Kaimana antara suku orang asli Papua yang berasal dari pantai dengan yang berasal dari pedalaman dan bagaimanakah hubungan antara orang asli Papua dan pendatang terkait masalah tersebut. Studi ini menunjukkan bahwa hak kesulungan di Kaimana merupakan wacana sekaligus strategi yang dilemparkan oleh suku-suku di Kaimana yang selama ini merasa dipinggirkan dan sumber dayanya diambil oleh para pendatang. Jika diamati secara mendalam, hak ini dapat dimaknai sebagai kebutuhan akan adanya pengakuan terhadap suku-suku tersebut. Persoalan yang penting tidak terletak pada siapakah orang Kaimana asli tetapi bagaimanakah cara yang tepat untuk memberikan rekognisi terhadap kelompok-kelompok atau suku-suku yang selama ini tertinggal dalam pembangunan di Kaimana. Dimensi yang tidak kalah pentingnya adalah relasi sosial antara orang Kaimana dengan pendatang. Relasi sosial pendatang dengan orang-orang Kaimana juga dipengaruhi oleh pembedaan agama. Orang-orang Kaimana yang beragama Islam merasa memiliki hubungan yang lebih dekat dengan para pendatang yang beragama Islam walaupun hal ini tidak berlaku secara umum. Kerangka analisis studi ini menggunakan kerangka teori identitas dan etnisitas untuk melihat persoalan tersebut. Apakah pendefinisian identitas dan etnis menurut teori-teori sosiologi masih relevan untuk memahami persoalan klaim identitas etnis di Kota Kaimana.
\end{abstract}

Kata kunci: kontestasi identitas, orang pantai, orang pedalaman, tanah adat, dan hak pertuanan

\section{Pendahuluan}

Secara teoritik, kategori orang asli Papua dan pendatang pada dasarnya kurang tepat secara ilmiah mengingat identitas yang dimaksud bersifat konstruksi sosial. Penggunaan kategori analitik orang asli cenderung menjadikan pendekatan dalam penulisan ini bersifat esensialis, namun unit analisis dalam artikel ini, yakni pada level kelompok-kelompok etnis orang Papua, memerlukan adanya perbedaaan 
antara orang asli dengan pendatang. Pertanyaan yang sulit dijawab dalam wacana etnisitas di Kaimana sampai saat ini adalah siapakah orang asli Papua di Kaimana atau disebut dengan orang asli Kaimana. Pandangan mainstream yang berkembang dalam Dewan Adat Kaimana, orang asli Papua di Kaimana, walaupun masih dalam perdebatan di antara para anggotanya adalah mencakup suku-suku yang anggotanya cukup besar yakni: Irarutu, Kuri, Kuripasai, Mairasi, Kambrauw, Madewana, Koiwai, dan Napiti. Pandangan ini merupakan derivasi dari pendefinisian orang asli Papua dalam UU No. 21/2001 tentang Otonomi Khusus yang menyebutkan bahwa orang asli Papua adalah anggota masyarakat adat dari suku-suku Melanesia.

Berdasarkan pengalaman objektif orang Kaimana sesudah jatuhnya Orde Baru, penggunaan kategori analitis tersebut menjadi relevan karena dikaitkan dengan pertarungan dalam ranah politik dan ranah ekonomi. Konsep pendatang pada dasarnya dikonstruksi secara sosial dan politik oleh elit-elit Kaimana yang merujuk pada orang-orang Tionghoa, Arab, dan berbagai suku dari luar Papua. Keberadaan berbagai suku pendatang tersebut di Kota Kaimana lebih dahulu daripada suku-suku orang asli Papua yang turun dan membentuk kampung pada tahun 1950-an. Berbagai hasil penelitian sejarah dan arsip Belanda menjelaskan bahwa keberadaan perkampungan untuk orang-orang Seram, Buton, dan Tionghoa di Kaimana telah ada sebelum kedatangan Belanda pada akhir abad ke-19.

Berdasarkan uraian tersebut, penelitian ini menjawab beberapa pertanyaan sebagai berikut; Pertama, bagaimana kontestasi antarsuku orang asli Papua dalam memperebutkan hak pertuanan di Kaimana? Sesudah Kota Kaimana menjadi ibu kota Kabupaten Kaimana, sebagian besar suku-suku di Kabupaten Kaimana mengakui bahwa Kota Kaimana dibangun di atas tanah milik mereka. Kedua, bagaimana strategi kelompok suku-suku pedalaman untuk memperjuangkan klaim hak pertuanan atas tanah di Kota Kaimana? Ketiga, bagaimana hubungan antara orang asli Papua dengan pendatang terkait hak pertuanan di Kaimana? Dalam penelitian ini, istilah Kaimana merujuk pada Kecamatan Kaimana yang dikenal dengan Kota Kaimana, ibu kota Kabupaten Kaimana.

\section{Metode Penelitian}

Metode penelitian dalam tulisan ini adalah menelaah literatur yang membahas masalah hak-hak pertuanan di Kaimana. Pengamatan dan wawancara juga dilakukan pada suku-suku pedalaman dalam memperjuangkan klaim hak pertuanan. Demikian pula dalam mengamati dan mewawancari, dalam rangka memahami bagaimana hubungan antara orang asli dengan pendatang.

\section{Hasil dan Pembahasan}

Masalah yang dikaji dalam penelitian ini adalah mengenai perebutan hak pertuanan di Kaimana antara suku-suku pantai dan pedalaman. Para pelaku sosial yang terlibat dalam kontestasi tersebut menggunakan klaim identitas etnis sebagai dasar untuk menuntut hak pertuanan. Hampir setiap suku mengakui bahwa mereka adalah orang-orang pertama yang menempati Kaimana, dan berhak disebut sebagai orang asli beserta seluruh hak yang melekat. Oleh karena itu, kerangka analisis studi ini menggunakan kerangka teori identitas dan etnisitas untuk melihat persoalan tersebut. Apakah pendefinisian identitas dan etnis menurut teori-teori sosiologi masih relevan untuk memahami persoalan klaim identitas etnis di Kota Kaimana.

Identitas seringkali dimaknai sebagai pemahaman mengenai siapa diri kita dan siapa orang lain, serta pemahaman orang lain mengenai siapa dirinya sendiri dan siapa orang lain (Jenkins 2004: 5). Konstruksi identitas dalam studi ini lebih terkait dengan wacana etnisitas. Istilah etnisitas berasal dari Bahasa Perancis ethnie dan diserap ke dalam Oxford English Dictionary pertama kali pada tahun 1953 (Downman 2004). Kata etnisitas dalam kamus tersebut dapat dimaknai sebagai sebuah kelompok etnis tertentu atau sifat-sifat yang dimiliki oleh suatu kelompok etnis tertentu. Istilah ini belum meluas sampai 1960-an dan pertama kali digunakan secara luas di Amerika Serikat (Downman 2004 Rex 1985). 
Malasevic (2004) menyebutkan bahwa terminologi etnisitas berakar dalam Bahasa Latin, yaitu dari kata ethnos atau etnikos yang artinya ialah non-Hellenic. Selanjutnya, pemaknaan terhadap istilah ini berkembang menjadi non-Yahudi, non-Kristen atau orang-orang kelas dua. Menurutnya, wacana etnisitas secara sosiologis telah dimunculkan oleh D. Riesman pada tahun 1953 untuk merujuk pada bentuk khusus dari perbedaan kebudayaan. Malasevic (2004) juga menjelaskan bahwa tradisi AngloAmerika menggunakan etnisitas untuk menyebut pelbagai kelompok minoritas dalam masyarakat sementara tradisi Eropa menggunakan etnisitas ebagai sinonim dari kebangsaan yang didefinisikan secara historis.

Etnisitas juga menjadi kajian dari para pemikir sosiologi klasik. Weber (1978) mendefinisikan kelompok etnis sebagai kelompok sosial yang memiliki kepercayaan subjektif dalam asal-usul yang sama karena kemiripan ciri-ciri fisik, tradisi, atau karena kenangan pada masa penjajahan dan migrasi, dan tidak terkait apakah ada hubungan-hubungan darah secara objektif atau tidak, sedangkan Marx (1844/2012) meletakkan etnisitas sebagai suprastruktur dalam masyarakat kapitalis dan mencerminkan kekuasaan tertinggi kelas sosial secara historis. Sementara, Durkheim (1984) menjelaskan tentang klan, yaitu ikatan sosial yang terbentuk berdasar hubungan kekeluargaan sebagai tempat berkembangnya solidaritas mekanis, yakni solidaritas sosial yang muncul karena persamaan kesadaran antar anggota-anggota masyarakat yang berfungsi sebagai dasar integrasi sosial. Menurutnya, modernisasi tidak menghancurkan ikatan-ikatan etnisitas melainkan menciptakan komunitas moral superior, sedangkan dengan perspektif Simmel (1950), etnisitas dapat dilihat sebagai bentuk interaksi sosial, yaitu suatu bentuk di mana individu-individu tumbuh bersama dalam kelompok-kelompok untuk memenuhi kebutuhannya, berdasarkan unsur-unsur budaya.

Pendefinisian etnis dalam perkembangannya merujuk pada Barth (1988) yang menjelaskan identitas etnis dikonstruksi secara sosial. Jika dibandingkan dengan pendefinisian identitas oleh Berger dan Luckman (1979) bahwa identitas merupakan produk dari konstruksi sosial yang dibentuk, dipertahankan, dan dimodifikasi dalam interaksi sosial, maka pemikiran Weber (1978), Barth (1988), Kellas (1998), dan Hall (1999) banyak memiliki persamaan bahwa identitas ialah sesuatu yang bersifat instrumental dan terbangun secara sosial.

Pendefinisian identitas yang digunakan dalam studi ini cenderung kepada pemikiran Barth yang menyebutkan bahwa identitas suatu kelompok etnis dikonstruksi, direproduksi, dan dipertahankan secara sosial, sedangkan istilah etnis menurut Weber (1978) dan Durkheim (1984) ialah kelompok sosial yang memiliki kepercayaan subjektif bahwa mereka berasal dari keturunan yang sama dan kepercayaan ini berimplikasi pada terciptanya ikatan kekeluargaan. Kedua definisi tersebut digunakan untuk menganalisis hubungan antar suku orang asli Papua di Kaimana, dan hubungan suku-suku tersebut dengan komunitas pendatang. Asumsi teoretik yang dibangun dalam studi ini adalah: (1) kontestasi antar kelompok suku orang asli Papua di Kaimana dalam memperjuangkan hak pertuanan menggunakan pendekatan identitas yakni mengklaim bahwa kelompok sukunya yang datang pertama kali di Kaimana; (2) kontestasi juga terjadi antara kelompok suku orang asli Papua dengan kelompok suku-suku pendatang di Kaimana.

\section{Klaim hak pertuanan suku pantai}

Batas-batas sosial menurut Barth (1988) dapat dilihat dari penanda identitas suatu kelompok etnis. Penanda-penanda identitas tersebut juga melekat dengan segala konsekuensinya termasuk sejarah, dan hak kepemilikan atas sumber daya yang dimiliki oleh kelompok etnis tersebut. Sejarah dan hak-hak tersebut juga dikonstruksi dan direproduksi secara sosial dalam hubungannya dengan kelompok etnis lain. Hak pertuanan atas tanah Kota Kaimana menjadi fokus bahasan studi ini yang akan dilihat dalam perspektif konstruksi batas-batas identitas etnis secara sosial. Klaim atas hak pertuanan tersebut didasarkan atas kepercayaan subjektif terhadap mitos-mitos tentang nenek moyang mereka yang berfungsi menjadi penanda identitas. Secara yuridis, hak pertuanan seperti ini diakui sebagai identitas budaya masyarakat, sebagaimana diatur dalam UU No. 39/1999 tentang HAM. 
Secara konseptual, hak atas pertuanan selalu berhubungan dengan identitas seseorang atau kelompok masyarakat yang mengklaimnya. Keberadaan masyarakat adat ditandai oleh berlakunya hukum adat yang disertai dengan pengaturan penguasaan sumberdaya yang melekat seperti tanah pertuanan atau perairan. Kepemilikan sumberdaya dalam masyarakat adat bersifat kolektif, sehingga dapat menjadi penanda identitas komunitas masyarakat tersebut. Misalnya, tanah di Kota Kaimana dengan batasbatas tertentu adalah milik suku tertentu, sehingga tanah tersebut menjadi penanda identitas dari keluarga-keluarga yang menjadi anggota suku tersebut. Dengan demikian, tanah pertuanan dalam tingkatan tertentu menunjukkan identitas dari suatu suku tertentu. Pada tingkatan individual, ketika seseorang menanamkan usahanya terhadap sejengkal tanah, maka ia menciptakan identitas pada diri dan tanahnya tersebut (Aass 1984). Hal ini dimaknai bahwa pengerjaan tanah, terutama pertanian, adalah bentuk ekspresi dari eksistensi diri yang mendapatkan pengakuan dari komunitas masyarakatnya.

Istilah tanah pertuanan dalam konteks nasonal didasarkan atas hukum adat yang mengakui adanya hak pertuanan (Beschikkingsrecht) atau persekutuan atas tanah (Van Vollenhoven 1909, Suharsiningsih 2009). Supomo menggunakan istilah hak pertuanan untuk menyebut persekutuan hak atas tanah dalam masyarakat adat. Persekutuan tersebut memiliki hak atas tanah yang ditempati para anggota persekutuan dan tanah tersebut digunakan untuk memenuhi kelangsungan hidup anggotanya (Soehardi 1979). Hak pertuanan berimplikasi ke luar bahwa orang di luar persekutuan tidak diperbolehkan untuk mengeksploitasi, dan mengambil keuntungan dari tanah tersebut.

Pengertian mengenai hak pertuanan seperti ini sejalan dengan konsep pertuanan yang dipahami oleh masyarakat adat Kaimana. Pandangan tersebut bersumber dari Pasal 1 (s) UU No. 21/2001 tentang Otonomi Khusus Papua yang mengakui hak persekutuan yang dimiliki oleh masyarakat hukum adat tertentu atas suatu wilayah tertentu yang meliputi hak untuk memanfaatkan tanah, hutan, dan air serta isinya. Sejumlah wawancara menyebutkan bahwa hak pertuanan adalah hak dari komunitas suku tertentu untuk memiliki dan menggunakan sejumlah tanah yang diyakini telah diwariskan oleh nenek moyang atau keluarga mereka pada masa lalu. Dengan demikian, hak pertuanan atau hak ulayat selalu melekat sebagai identitas suatu kelompok suku.

Perbedaannya dengan konsep hak pertuanan dalam hukum adat, orang asli Kaimana menyebutkan istilah hak kesulungan, yakni sejumlah privileges yang dimiliki oleh suku tertentu yang datang pertama kali di suatu wilayah. Hak kesulungan adalah prasyarat untuk memperoleh hak pertuanan atas suatu wilayah adat jika dalam wilayah tersebut ditempati oleh lebih dari satu suku orang asli Papua. Dasar yang digunakan untuk menentukan hak kesulungan atau hak pertuanan adalah orang dari Suku Mana yang pertama kali menetap di Kaimana. Karena tidak ada bukti tertulis mengenai siapa yang datang pertama kali, setiap suku mengonstruksi mitos atau cerita-cerita nenek moyang yang digunakan sebagai klaim identitas orang asli Kaimana.

Pertuanan di Kaimana sampai sekarang menjadi persoalan yang sedang diperdebatkan oleh suku-suku besar meskipun telah dilakukan penelitian mengenai tanah ulayat di Kaimana oleh tim peneliti dari Universitas Cenderawasih. Fakta empiris menunjukkan bahwa Kota Kaimana sampai dengan Kampung Krooy menjadi wilayah pertuanan orang Koiwai atau suku pantai terutama keluarga Lawai (Silzer \& Heikinnen 1984, Widjojo 2009, Luthfi 2012). Hasyim Lawairao, putra Kepala Pertuanan Keluarga Lawai yakni Moi Laway, juga mantan Kepala Kampung Krooy menceritakan bahwa Moi Lawai mendapat gelar dari Raja Komisi sebagai Kapitan Lawairauw, dan berkuasa atas tanah-tanah di pertuanan Lawairauw dari Kaki Air Kecil sampai Wamansala. Sekarang ini pertuanan tersebut menjadi Kampung Krooy. Menurut Hasyim, Raja Komisi membagi Kota Kaimana ke arah Timur sampai Kampung Coa ke dalam empat pertuanan sebagai berikut: Kota Kaimana sampai Kaki Air kecil (Wamansala), merupakan hak pertuanan Aituarauw (keluarga Raja Komisi) dan Tambawang; Wamansala sampai Warara (Air Merah) merupakan hak pertuanan dari Lawairao; Warara sampai Kali Tioram dan Tanjung Simora, merupakan hak pertuanan keluarga Sinatarouw dan Simorarouw karena keduanya bersaudara; Airport (Gunung Dullah) sampai Coa Lama milik pertuanan keluarga Yerfisirouw (Wawancara Hasyim Lawai 23 Desmber 2008). 
Kota Kaimana ke arah Barat sampai Tanjung Bitsyari merupakan hak pertuanan keluarga Sirua yang pada masa lalu keluarga ini dipimpin oleh Kapitan Bitsyari Sirua. Baik Sirua maupun Lawai menyatakan bahwa mereka adalah representasi Suku Pantai (Koiwai) meskipun hal ini masih diperdebatkan. Beberapa sumber menyebutkan bahwa Lawai adalah orang keturunan Suku Kamoro dan Sirua adalah keturunan Suku Mairasi. Kedudukan keluarga Lawai di Kaimana adalah sangat penting karena keluarga ini yang menguasai tanah di kawasan Kampung Krooy, dan mereka telah banyak memberikan tanah kepada para pendatang dari luar Kaimana dan Papua. Demikian juga keluarga Bitsyari yang tidak kalah penting karena salah seorang perempuan dari keluarga ini menikah dengan Raja Komisi, Achmad Aituarauw, dan Kapitan Bitsyari menikah dengan perempuan keturunan Arab yang telah menurunkan ulama-ulama besar di Kaimana.

Menurut cerita seorang mantan pendayung Raja Namatota, Ubas Nabombo, dahulu ada empat orang yang keluar dari lubang Gunung Rewai (Wawancara 19 Januari 2009). Dua bersaudara yakni Mapui dan Upiyana turun ke Teluk Bisari dan membuat perapian. Orang-orang dari kejauhan memanggil mereka dengan sebutan siruit yang artinya dua orang. Mapui melahirkan Hanis, kemudian Hanis memiliki anak bernama Mubasei. Anak dari Mubasei bernama Airfatan Sirua. Lasaea Sirua, kakak dari Boy Lawan Sirua, merupakan putra Airfatan Sirua yang terkenal dengan sebutan Kapitan Bitsyari, penguasa Tanjung Bitsyari.

Jika kita melihat tanah di Kaimana menurut perspektif keluarga Lawai, maka secara keseluruhan hanya ada lima pertuanan besar di Kaimana yang berkuasa atas tanah. Menurut keluarga Lawai, Suku Kambrauw dan Suku Mairasi menuntut bahwa tanah di Kota Kaimana ialah milik mereka, namun fakta menunjukkan bahwa mereka tidak ada yang pernah tinggal di daerah ini. Perkebunan di Bantemin sejak masa Belanda ditanami oleh orang-orang Buton dan orang-orang pantai dengan pohon kelapa, pisang, dan coklat. Mereka menjual hasil tanaman tersebut ke Kota Kaimana. Pada masa awal kedatangan Belanda (1858-1942), keluarga Lawairouw berjumlah tiga keluarga yang masih bersaudara yakni Lawairouw, Moy Lawairouw, dan Nasohor Lawairouw.

Menurut Hasyim, sumbangan Keluarga Laway kepada Kaimana di antaranya berupa tanah yang dihibahkan sebagai berikut: (1) Pembangunan Gereja Katolik, Gereja Pentakosta, dan Gereja Protestan Indonesia Krooy masing-masing 30 x 80 M, (2) Masjid Krooy 50 x 50 M di Air Merah, dan (3) Kantor Pemda Kaimana dari Dinas Pendidikan dan kebudayaan sampai Kaimana Beach Hotel. Ketika ditanya motivasinya, Hasyim mengatakan bahwa bangunan pemerintah dan gereja bertujuan untuk melayani masyarakat sehingga keluarganya memberikan dengan sukarela.

Perspektif kedua datang dari Senin Simora, Kepala Pertuanan keluarga Simora (Wawancara Senin Simora 24 Desember 2008). Menurutnya, sebelum Jepang masuk ke Kaimana, Raja Komisi dengan kuasa Belanda telah menetapkan batas-batas pertuanan di Kaimana dari Wamansala sampai Tanggrome di Coa Lama menjadi milik marga Namsao. Di situ telah berkembang keluarga Watora, Sirfefa, dan Yerfisi, sedangkan keluarga Simorarao dan Sanatarao memiliki hak pertuanan dari Warara (Air Merah) sampai dengan Kali Tioram melewati Tanjung Simora atau dari Warara Tarneta sampai dengan Freiwalla (Kali Tioram). Leluhur dari keluarga Simora ialah Suariris Simora, Nariu Simora hingga Senin Simora. Sebelum Belanda masuk ke Kota Kaimana, keluarga Simora tinggal di Bantemin di mana Mayor Simora diangkat sebagai Kepala Kampung oleh Raja Komisi dengan kuasa Sultan Tidore. Mayor Simora merupakan nenek moyang keluarga Simora.

Sebelum pemekaran Kabupaten Kaimana, hak pertuanan di daerah ini belum diperebutkan antara suku-suku pantai dengan pedalaman. Sesudah pemekaran menjadi Kabupaten Kaimana, keluarga Watora dan Kurita dari Teluk Arguni, menggugat hak pertuanan keluarga Simorarao dan Sanatarao yang dikategorikan ke dalam Suku Koiwai. Mereka mengklaim bahwa tanah di Kaimana secara adat menjadi hak pertuanan suku-suku yang tinggal di pedalaman Teluk Arguni karena Suku Koiwai yang menempati dari Pulau Namatota sampai Pulau Adi diragukan keasliannya sebagai orang Papua oleh suku-suku pedalaman. Keaslian diukur dari identitas ragawi, yakni rambut keriting dan kulit gelap 
yang merupakan ciri kas orang asli Papua. Sedangkan suku Koiwai dianggap merupakan hasil percampuran antara orang asli Papua dengan suku-suku pendatang.

Menurut Senin Simora, Kurita turun dari Teluk Arguni pertama kali tinggal di Kampung Seram dan oleh Raja Komisi, Ahmad Aituarauw, diberikan tanah untuk tinggal di Perumahan Bunsur, Kaimana, sampai sekarang. Menurut pengakuan Simora, keluarga Simorarao dan Sanatarao telah tinggal, dan menetap secara turun temurun di Bantemi. Pada saat menjangkitnya penyakit kolera, keluarga Simora ikut lari sampai Iraran. Sesudah beberapa lama menetap, keluarga Simora kembali ke Bantemi. Penyerahan keluarga seringkali berhimpitan dengan penyerahan kekuasaan. Misalnya, pada saat itu, Suariris Simorarao meninggal dunia, keluarganya diserahkan ke keluarga Hamis Sanatarao di mana Hamis menikah dengan istri Suariris Simorarao. Kemudian, wilayah Bantemi diserahkan oleh Hamis Sanatarao kepada Kapitan Moy Lawai di Kampung Krooy. Dengan demikian, keluarga Simora pindah ke Kampung Krooy. Pada waktu itu, Kampung Krooy dijaga oleh Warnamen, penjaga kampung, Salim Werfete yang diangkat oleh Raja Komisi. Sementara Kampung Coa dipimpin oleh Kapitan Matua, kemudian hari dimekarkan menjadi Coa Lama dan Matua.

Perspektif lain datang dari keluarga Watora yang masih keturunan Kapitan Matua, Keluarga Yerfisirao. Menurut Ahmad Watora, kepala pertuanan keluarga Watora di Matua, batas ulayat Pertuanan Watora yang memiliki batas wilayah dari Kampung Coa sampai dengan Tuahrome (Wawancara 3 Januari 2009). Kakek dan nenek Watora datang pertama kali di Tuahrome, Coa lama. Mereka diberikan amanah oleh orang-orang tua di Mairasi untuk menjaga orang-orang Mairasi yang turun, dan menetap di daerah ini. Dalam perkembangannya, orang-orang di Coa lama berpindah sebanyak empat kali ke Tuahrome, Kampung Tengah, kelapa I Fisdema, dan kampung Baru Matua.

Mereka berpindah dari satu kampung ke kampung yang lain karena penjajahan Belanda membuat banyak orang tertekan secara psikologis. Akibatnya, mereka berpindah-pindah guna menghindari orang Belanda. Asal mula keluarga Watora ialah di Bukwer, Arguni. Nenek moyangnya yang turun dan menetap di Tuahrome, Kaimana, ialah Kapitan Berani Watora dan dua orang suadaranya. Di Teluk Arguni, marga yang paling besar ialah Watora yang menetap dari Susunu, Seraran, sampai Bukwer. Ketika menetap ke Tuahrome, mereka sudah beragama Islam.

Orang-orang yang tinggal di Teluk Arguni terpisah oleh teluk. Di sebelah kanan ialah orang-orang Mairasi sementara orang-orang di sebelah kiri ialah Irarutu dan Kuri. Watora membawa orang-orang dari Arguni untuk tinggal di Kampung Coa Lama, Kaimana, yang batasnya sampai Gunung Dulang. Tempat ini diberikan kepada keluarga Watora untuk menjaganya. Kapitan Berani menikah dengan Meskeri Furu yang juga berasal dari Teluk Arguni. Orang-orang dari Teluk Arguni yang datang ke Namatota singgah dulu di kampung Coa lama untuk beristirahat. Beberapa orang menetap di sini dan menikah dengan keluarga Watora. Beberapa fam lain dari teluk Arguni yang tinggal di sini ialah Sirfeva. Keluarga Sirfeva mendapat hak pertuanan di Kampung Coa lama yang disetujui oleh Raja Namatota. Setelah Watora menikah dengan keluarga Maskeri Furu, Sirfefa turun dan menikah dengan salah satu keluarga Watora. Coa dalam Bahasa Irarutu berarti tempat persinggahan.

Imran Furu, salah seorang yang menetap di Matua, menceritakan bahwa Raja Komisi, keluarga Aituarauw, tidak memiliki hak pertuanan di Kaimana (Wawancara 3 Januari 2009). Menurutnya, Raja Komisi menetap di Kaimana, akan tetapi hak pertuanannya di Pulau Adi. Raja Komisi tinggal di Kaimana karena Raja Namatota mengangkatnya sebagai komisioner untuk mengawasi, dan menyampaikan perintah kepada masyarakat yang tinggal dari Nusa Ulan sampai Babo, Timika. Oleh karena itu, Raja Komisi seharusnya tidak dapat menjual tanah di Kota Kaimana. Raja ini memiliki tanah di Kota Kaimana karena diberikan oleh Raja Namatota sebagai balas jasa karena telah membantu tugas-tugasnya.

Salah seorang dari keluarga Bitsyari menjelaskan bahwa Raja Komisi telah diberikan hak pertuanan oleh Kapitan Bistari yang mencakup wilayah Kota Kaimana karena hubungan perkawinan sebagaimana telah dijelaskan di muka. Menurut keluarga Watora dan Furu, keluarga Aiturauw merupakan hasil percampuran antara orang Papua dengan orang Seram, Maluku. Mereka pertama kali 
singgah ke Pulau Adi, dan salah satunya menikah dengan Musmafa dari Teluk Arguni-Mairasi. Sedangkan keluarga Raja Ombaiyer, Namatota, berasal dari Teluk Arguni, turun ke Namatota setelah diberikan amanah oleh musyawarah ketua-ketua suku Mairasi, Irarutu, Kuri, dan Baham.

Pengangkatan Raja Komisi oleh Raja Ombaiyer karena munculnya perang antarsuku orang asli Papua, dikenal dengan hongi-hongi. Situasi ini menuntut raja untuk menghentikan peperangan sesama orang asli Papua agar tidak jatuh korban yang lebih banyak. Selain itu, karena wilayah Kerajaan Namatota terlalu luas dari Teluk Nusa Ulan, perbatasan Fak-fak, sampai dengan Babo, Timika. Raja Ombaiyer memanggil Raja Komisi untuk mendengar keluhan-keluhan dari masyarakat. Jabatan Raja Komisi terbentuk sejak zaman Belanda untuk membantu tugas-tugas administrasi Raja Namatota. Pada kenyataannya, secara historis serta kebudayaan, masyarakat di Kabupaten Kaimana hanya mengenal satu raja, yaitu Raja Ombaiyer dari Namatota (Widjojo dan Rusdiyati 2014).

Pertuanan di Kampung Matua diberikan hak kepada keluarga Watora untuk menjaganya. Sekarang ini, keluarga Watora memberikan sebagian haknya kepada keluarga Sirfefa. Setelah menikah dengan keluarga Watora, nenek moyang Sirfefa turun ke daerah Kota Kaimana. Kemudian, Maskeri Furu mengangkatnya untuk menjaga hak tanah yang berada di Coa lama, sedangkan Watora menjaga tanah di Kampung Baru Matua. Suku Irarutu yang memberikan nama Kampung Coa yang berarti tempat persinggahan. Menurut cerita nenek moyang Irarutu, para utusan dari berbagai kampung di Teluk Arguni singgah di Coa sebelum melanjutkan perjalanan menghadap Raja Namatota. Keluarga Furu yang menjadi pengawal nenek moyang orang-orang dari Teluk Arguni yang mengadakan perjalanan ke Namatota dari kampung Coa.

Menurut keluarga Watora, Kaimana dapat dimaknai sebagai amanah atau kota yang diamanhkan. Kabupaten Kaimana yang membentang dari Teluk Arguni sampai Teluk Etna adalah warisan yang diberikan kepada orang-orang Mairasi, Irarutu, dan Kuri yang diberikan oleh nenek moyang mereka. Hal ini didasarkan atas mitos bahwa pada masa lalu, seluruh nenek moyang berasal dari Gunung Nabi, Teluk Arguni. Menurut hikayat Gunung Nabi, seluruh dunia tenggelam oleh banjir sehingga orangorang terpilih dari setiap bangsa yang berada dalam Kapal Nabi Nuh terdampar di Gunung Nabi, Arguni. Setelah banjir selesai pada masa Nabi Nuh, orang-orang dari semua bangsa menyebar ke berbagai penjuru dunia (Iribaram 2011). Berdasarkan UU No. 21/2001 tentang Otonomi Khusus Papua, terutama pasal 1, Penguasaan atas tanah di Kaimana dapat dibedakan menurut status hak pertuanan (hak ulayat) dan hak garap. Mereka yang dianggap memiliki hak pertuanan ialah orangorang Mairasi, Irarutu, dan Kuri di mana mereka memiliki hak untuk memiliki dan menjual tanah di samping memanfaatkan tanah. Namun, orang-orang suku-suku pendatang dari luar Kaimana yang baru datang, dan belum memiliki jasa terhadap kampung hanya memiliki hak garap setelah mendapatkan ijin dari kepala pertuanan di suatu kampung. Pihak yang memiliki otoritas untuk memberikan hak pertuanan secara formal adalah kepala daerah (bupati), namun harus mendapat persetujuan dari kepala suku. Hak pertuanan berarti orang-orang tersebut memiliki status tempat yang jelas sebagai orang asli Papua sebagaimana diamanatkan dalam UU No. 21/2001 tentang Otonomi Khusus Papua. Hal ini merupakan diskriminasi positif yang bertujuan untuk melindungi hak hidup orang asli Papua dari depopulasi dan eksploitasi sumberdaya alam oleh suku-suku pendatang.

Salah satu indikator orang asli Kaimana adalah nama-nama keluarga mengambil nama-nama batu, lubang batu, pohon, gunung, sungai dan danau di pedalaman Kaimana. Dalam perspektif keluarga Watora, keluarga Laway marga aslinya ialah Rewai karena mereka berasal dari Gunung Rewai yang turun ke Kampung Krooy. Mereka sekeluarga turun ke pantai dari Gunung Rewai setelah dipanggil oleh Kapitan Berani Watora. Keluarga Furu mengakui pertuanan Lawai dari Air Merah sampai dengan Kaki Air Kecil. Mereka menganggap keluarga Lawai adalah keturunan dari Suku Mairasi, Irarutu, dan pendatang.

Salah seorang imam dari Kampung Nusaulan Buruwai, Abid Samai, memberikan komentar atas klaim tanah ulayat di Kaimana sebagai berikut. Berkaitan dengan konflik perebutan hak untuk menjadi tuan di Kaimana, suku-suku tersebut belum menggunakan logika yang tepat. Misalnya bahwa setiap suku 
memiliki masing-masing wilayah pertuanan di daerah asalnya (Wawancara 6 Januari 2009). Orang suku Mairasi dan Kambrau mengklaim bahwa mereka yang memiliki Kaimana, namun wilayah pertuanan mereka di Teluk Kambrau dan pergunungan Mairasi. Setiap suku itu sudah memiliki tempat masing-masing baik hutan, gunung, teluk, dan pantai. Imam Abid menyarankan bahwa semua suku seharusnya menghormati dan menghargai suku-suku pantai yang dikenal sebagai Koiwai di mana mereka telah menetap lama di Kaimana seperti Laway, Sanatarauw, Simorarauw, Sirua. Pada realitasnya, sejak masa kolonial, setiap pendatang yang meminta tanah kepada Raja Komisi akan diarahkan untuk memintanya kepada Kepala Pertuanan Moy Lawai.

\section{Klaim hak pertuanan suku-suku pedalaman}

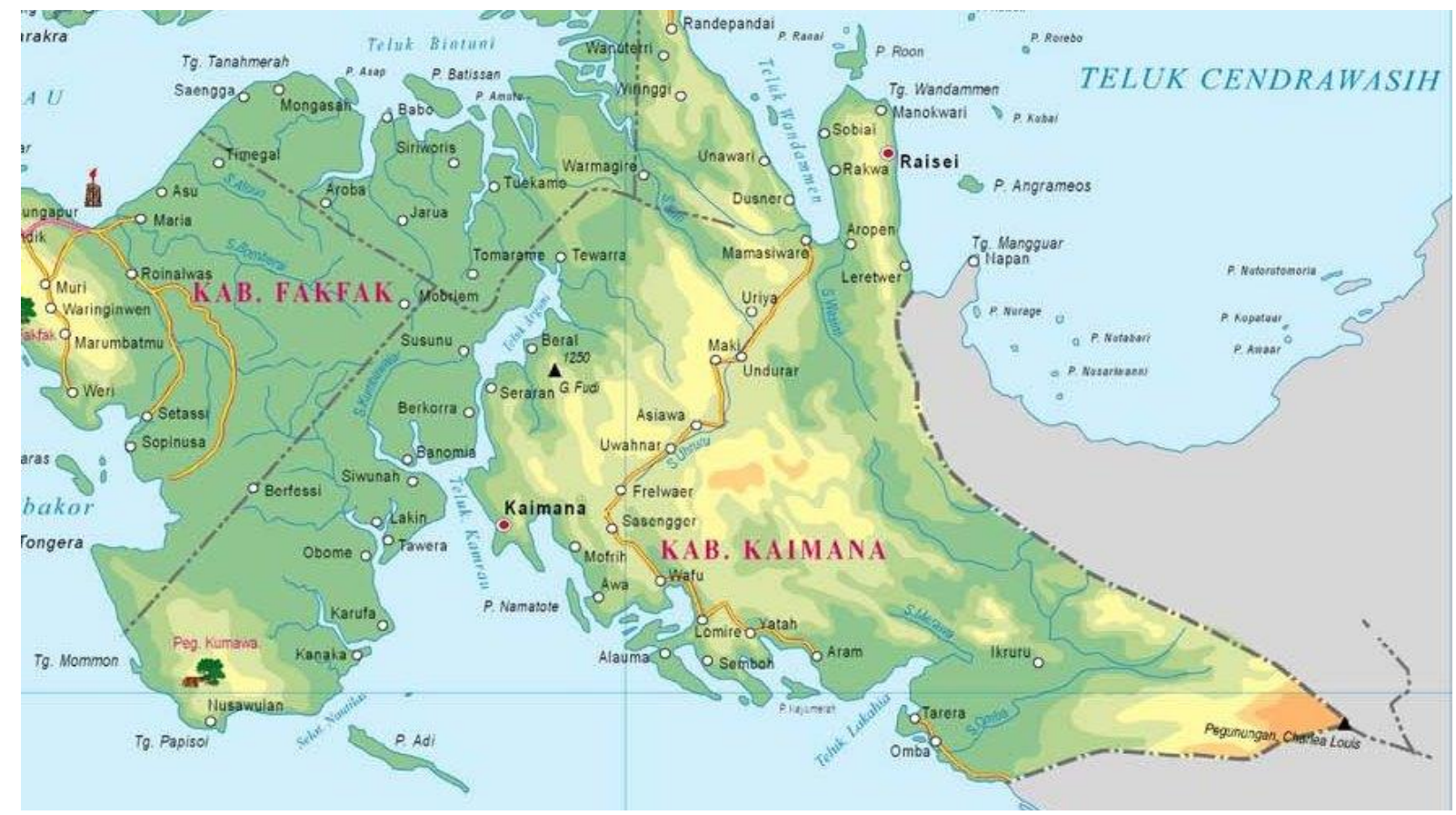

Gambar 1.

Peta Kaimana

Penguasaan tanah di Kota Kaimana yang telah ditetapkan oleh Raja Komisi pada masa Belanda mendapatkan banyak tantangan dari orang-orang asli Papua yang berasal dari pedalaman, yakni Mairasi, Teluk Arguni, dan Teluk Kambrauw (Luthfi 2012). Permasalahan yang sering dikemukakan oleh orang Koiwai di Kaimana adalah mengapa klaim tersebut muncul sesudah Kaimana menjadi kabupaten atau mengapa klaim tersebut tidak muncul pada masa Orde Baru atau sebelum Kaimana menjadi kabupaten? Persoalan lain yang juga muncul adalah bahwa klaim-klaim mereka didasarkan atas cerita-cerita mitologi yang kebenarannya tidak dapat diverifikasi secara empiris atau ditulis dalam arsip sejarah.

Abdul Qodir Kurita, salah seorang tokoh masyarakat dari keluarga Kurita, menceritakan bahwa pada masa lalu Kaimana masih berupa lautan, dan yang ada hanya pulau-pulau termasuk Pulau Kuburan Cina (Wawancara 31 Januari 2009). Setelah itu, air laut menjadi surut dan orang-orang dari Teluk Arguni mulai datang ke Kaimana. Nenek moyang Kuri (Kurita) datang dari Teluk Arguni ke Kaimana, dan bertempat tinggal di Tanjung Simora. Kemudian, datanglah Furu ke Lubang Batu, dan bertempat tinggal di Mangga Dua. Sedangkan keluarga Watora yang migrasi ke Kaimana bertempat tinggal di Kampung Coa. Setelah migrasi orang Rewai dari Gunung Rewai ke Kaimana, nama Reway berubah menjadi Lawai karena pengaruh orang Buton di sana.

Dalam perspektif keluarga Kurita, tanah-tanah di Kaimana adalah milik keluarga Kurita, Furu, Watora, dan Rewai yang dibagi ke dalam beberapa wilayah sebagai berikut: Kurita menguasai 
Tanjung Simora; Furu memiliki Mangga Dua; Watora menguasai Matua; dan Rewai menjadi tuan di Kaki Air. Setelah itu, baru berdatangan para pendatang dari luar Kaimana yakni orang-orang Seram, Tionghoa, dan Buton untuk aktivitas barter. Mereka menetap di Kaimana sambil membawa barang seperti piring, pakaian, gula, dan komoditas lainnya untuk ditukar dengan burung cenderawasih, sagu, kayu damar, kulit lawang, dan masohi. Adapun nama Kurita diambil dari nama binatang yang masuk ke laut yang menyimbolkan penjaga agar perahu-perahu Arguni tetap bisa masuk dan keluar pelabuhan. Tugas Kurita adalah membersihkan lumpur agar tidak menumpuk di tepi pantai sehingga perahu dari Arguni yang ingin berlayar ke Namatota dapat berlabuh di Tanjung Simora. Dalam perspektif Kurita, Aituarauw itu dulu berasal dari Danau Siwiki kemudian berada di dalam batang kayu (disebut tuer), yang hanyut sampai ke Pulau Adi.

Raja Namatota berasal dari Teluk Arguni dan berlayar sampai Pulau Namatota. Waktu itu sudah ada orang kuat bernama Fenitiruma di Teluk Arguni, kemudian Ombaiyer menantangnya dalam undian puntung api. Pada saat gelombang datang, dilemparkanlah kedua puntung api mereka dan pemilik puntung api yang masih hidup akan menjadi raja. Puntung api Ombaiyer ternyata masih hidup karena dia menggunakan kekuatan gaib, oleh karena itu dia diangkat menjadi raja Namatota. Fenitiruma berjiwa besar dan menerima kekalahan itu, kemudian mengembara sampai Merauke. Baik Ombaiyer maupun Fenitiruma berasal dari Teluk Arguni. Ombaiyer berasal dari Bahasa Iraruru, Obawere, yang artinya pergi ke laut.

Mitos lain adalah keluarga Kurita datang pertama kali ke Tanjung Simora. Mereka memiliki satu orang putri, Putri Kori, dan seorang laki-laki, Kurita II. Ketika Kori ingin menikah, Kurita mengadakan sayembara barang siapa yang dapat melempar bola sepak raga tepat mengenai Putri Kori dari jarak jauh maka ia akan menjadi suaminya. Banyak orang dari Arguni dan Kambrauw ikut perlombaan tetapi sebagian besar peserta gagal kecuali Fenitiruma. Putri Kori kemudian menikah dengan Fenitiruma dan melahirkan Simorage yang berarti anak dari hasil pertandingan sepak raga. Nama tersebut kemudian hari berubah Simora, dan dijadikan nama Tanjung Simora. Mereka pindah dari tanjung ke kali kecil dekat Kecamatan Baru. Peristiwa tersebut menjadi penanda batas tanah antara milik Rewai dengan Kurita, yakni dari Kaki Air Kecil sampai dengan Air Tiba.

Sesudah itu, keluarga Furu datang dari Teluk Arguni, dan tinggal di batu lubang dekat Anda Air. Lama kelamaan, mereka pindah ke Mangga Dua, namun anak cucunya menyebar dari Anda Air hingga ke Krooy, sedangkan Watora datang di dekat Coa sampai dengan batas kali kecil. Pertuanannya adalah dari Bandara Kaimana sampai dengan Air Tiba. Berdasarkan cerita tersebut, Kurita menjelaskan bahwa wilayah pertuanan Kaimana terdiri atas: Kurita dari Air Tiba sampai dengan Tanjung Simora; Furu dari Batu Lubang sampai Krooy; Reway dari Kaki Air kecil sampai Air Tiba, dan Watora dari Kali kecil Bandara sampai Coa Lama.

Perspektif yang berbeda datang dari Ketua Suku Irarutu di Kaimana, Harun Sabuku, yang menegaskan bahwa sesama orang Papua di Kaimana masih bersaudara di mana nenek moyang mereka adalah Suku Mairasi dan Suku Kuri yang masih kakak beradik (Wawancara Harun Sabuku 1 Februari 2009). Menurutnya, suku-suku lain termasuk Suku Koiwai adalah keturunan dari dua suku besar tersebut yang telah bercampur dengan pendatang dari luar Papua. Konon kabarnya, semua manusia di kepala burung tersebar melalui empat jalan, orang tuanya lahir di Gunung Nabi dan keturunannya turun dari Gunung Nabi melalui rute-rute sebagai berikut: Irarutu turun dari Tugarni ke Teluk Arguni; Mairasi dari Kali Urere, terus ke Lobo, terus ke Teluk Triton; Kuri dari Kali Narmasa yang kemudian tembus hingga ke Teluk Bintuni; dan Wondama dari Kali Wosimi tembus ke Teluk Wondama.

Menurut Harun Sabuku, Kaimana pada masa lampau tidak berpenghuni. Orang-orang dari Kambrauw, Irarutu, dan Mairasi datang hanya untuk berburu tetapi tidak tinggal menetap. Kemudian, datang orang dari luar, yakni Seram, Tionghoa, dan Buton untuk berdagang serta menetap di sana. Sebagai buktinya terdapat Kampung Seram, Tionghoa, dan Buton tetapi tidak ada Kampung Kambrau, Kampung Irarutu, dan Kampung Mairasi di Kaimana. Baik pendatang maupun orang-orang 
Kambrauw, Mairasi, dan Irarutu diatur oleh Raja Namatota sehingga kehidupan menjadi lebih aman yang memungkinkan aktivitas barter berlangsung secara lancar.

Menurut Harun Sabuku, orang Koiwai ini berasal dari suku Irarutu dan Mairasi yang turun lebih dahulu. Mereka tinggal di pantai dan bertemu dengan orang asing terlebih dahulu. Mereka pada dasarnya merupakan orang Lobo dan Arguni, sehingga bahasa yang mereka gunakan atau Bahasa Koiwai menyerap kata-kata dari Bahasa Irarutu dan Mairasi. Orang Irarutu memahami sebagian katakata dalam Bahasa Koiwai, dan begitu pula sebaliknya bahwa orang Mairasi juga demikian, namun orang Koiwai tidak mengerti lagi Bahasa asli Irarutu dan Mairasi. Contoh, Sirua berasal dari kata si (dapat/lihat) dan rua (dua). Orang Kambrauw yang tidak mengakui Koiwai diduga kurang memahami sejarah persebaran orang Mairasi serta Irarutu ke pantai-pantai Kaimana pada masa lalu. Bahasa Koiwai juga menyerap kosakata dari orang Seram, Buton, dan Tionghoa, sehingga bahasa Koiwai tidak dapat dimengerti oleh orang Mairasi dan Irarutu yang belum pernah turun ke pantai. Dalam perspektif orang Irarutu, mereka turun dari Gunung Rewai ke Krooy, dan mengganti nama marga dari Rewai menjadi Lawai karena pengaruh orang Buton (Wawancara 1 Februari 2009). Rewai jika ditelusuri secara seksama bukan merupakan orang Koiwai karena asalnya adalah Irarutu gunung. Mereka yang disebut sebagai orang asli Kaimana, hak pertuanannya dari Kaki Air kecil sampai Air Merah (Air Tiba).

Van Peursen (1976) membagi tahap perkembangan kebudayaan menjadi tiga yakni mitis, ontologis, dan fungsional. Tahap mitis adalah suatu kondisi di mana manusia yang merasa dirinya dikelilingi kekuatan gaib, dikendalikan oleh alam dan sekaligus berintegrasi dengan alam. Pandangan orang Kaimana nampaknya masih dipengaruhi oleh kondisi mitis seperti ini. Cerita-cerita yang berasal dari tradisi lisan ini penting diketahui untuk memahami landasan kebudayaan dari klaim atas tanah yang sampai sekarang masih berlangsung di Kaimana. Misalnya, cerita mengenai perselisihan antara Kurita dengan Sanata dan Simorarauw atas pertuanan di Kaimana. Menurut tradisi lisan suku Irarutu, sebelum Kurita datang ke Kaimana, Fenitiruma telah datang ke tempat itu. Konon kabarnya seperti diceritakan oleh para tetua Irarutu, dahulu kala di Tanjung Simora ada gurita besar yang membunuh orang. Hal ini mengganggu perjalanan orang-orang Teluk Arguni yang hendak berlayar ke Pulau Namatota untuk menghadap Raja Ombaiyer karena karena mereka harus berlabuh di Kampung Coa untuk beristirahat menunggu angin teduh. Ketika mendengar ada gurita, Fenitiruma turun dari perahu dan berkelahi dengan binatang itu hingga akhirnya dia berhasil membunuh gurita raksasa ini. Kemudian ia menikah dengan anak gurita tetapi kemudian meninggalkan keluarganya guna meneruskan perjalanannya ke arah timur (Wawancara Harun Sabuku 1 Februari 2009, Dewan Adat Kaimana 2010, Tohari \& Luthfi 2011). Baik Kurita maupun Fenitiruma tidak memiliki hak pertuanan di Kaimana karena mereka tidak pernah menetap dalam waktu yang lama. Keturunan Fenitiruma dengan orang Irarutu sekarang menetap di Teluk Kambrau. Cara pandangan seperti ini berlawanan dengan pemikiran John Locke (1924) yang menyebutkan bahwa kepemilikan pribadi diperoleh seseorang ketika ia melakukan kerja terhadap properti yang tidak bertuan. Misalnya, lahan tak bertuan ketika diolah seseorang akan menjadi propertinya. Sementara, kepemilikan kolektif diperoleh oleh komunitas.

Berbeda dengan keluarga Fenitiruma, keluarga Kurita tetap menuntut kepemilikan lahan karena mereka telah turun temurun tinggal di Kaimana walaupun keberadaannya di Kaimana pada masa lalu menurut mitos hanya untuk berburu, sedangkan keluarga Simora berasal dari orang suku Irarutu yang menikah dengan perempuan dari suku Madewana. Mereka berbahasa Irarutu, dan menetap di Tanjung Simora di mana nama Simora berasal dari pertandingan sepak raga (simorage).

Menurut perspektif Harun Sabuku, ketua suku Irarutu di Kaimana, keluarga Watora menetap di Kampung Coa agar berdekatan dan dapat mendampingi Raja Komisi yang pertama kali berkedudukan di kampung ini. Kapitan Watora adalah pengawal Raja Komisi, dan membantu tugasnya sehari-hari (Wawancara 1 Februari 2009). Dengan demikian, pertuanan di Kaimana dalam perspektif Suku Iratutu adalah sebagai berikut: Rewai dari Kaki Air kecil sampai Air Merah; Simora dan Sanatarauw dari Air Merah sampai Tanjung Simora; Yerfisi dan Sirfefa, suku Irarutu yang menetap di Kaimana, dari Gunung Kerry sampai Coa lama; dan Sirua dari Kaki Air sampai Tanjung Bitsari, kemudian 
sebagian tanah keluarga Bitsari diberikan kepada keluarga Tambawang dan Raja Komisi karena ikatan pernikahan.

Sementara itu, salah seorang tokoh masyarakat Suku Kambrauw, David Aboda, menceritakan bahwa Kaimana sampai Namatota merupakan milik Suku Kambarauw berdasarkan mitologi Gawoda dan Mireta yang merupakan nenek moyang dari Suku Kambrauw (Wawancara 13 Februari 2009). Namanama nenek moyang Kambrauw yang sempat berjalan-jalan dan tinggal di Kaimana sampai Namatota pada masa lalu adalah Mireta, Gewoda, Gamabura, Assura, dan Samossa. Mereka turun ke Kaimana dari Teluk Kambrauw dan menamai tempat-tempat yang merentang dari Kaimana hingga Namatota dengan Bahasa Kambrauw. Menurutnya, Kaimana pada zaman nenek moyang hanya ditempati dan dimiliki oleh Suku Kambrauw, dan tidak ada suku lain yang tinggal di Kaimana. Mereka kembali ke Teluk Kambrau karena menyebarnya wabah penyakit kolera dan serangan orang-orang luar Papua yang menghancurkan kampung-kampung mereka di Kaimana. Studi Drooglever (2010) dan Widjojo (2014) menyebutkan bahwa pasukan Sultan Tidore seringkali melancarkan serangan ke orang Papua untuk mendapatkan budak.

Menurut Kepala Suku Kambrauw di Kaimana, Agus Tumanat, Kaimana dalam bahasa Kambrauw berasal dari kata 'emawa' yang berarti 'siapakah dia' (Agus Tumanat, FGD LIPI 20 Desember 2008). Hal ini merujuk pada orang-orang Kambrauw yang bertanya siapakah penghuni Pulau Kuburan Cina itu. Padahal, baik orang yang tinggal di Pulau Kuburan Cina maupun orang yang bertanya sama-sama berasal dari Suku Kambauw. Sebelum Belanda datang, orang Kambrauw sudah lebih dahulu menetap di sana, namun sesudah Belanda datang, banyak orang Koiwai yang menetap di Kaimana. Menurut Suku Kambrauw, hal ini disebut sebagai proses marjinaliasi terhadap Suku Kambaruw di Kaimana. Sebagai konsekuensinya, mereka berusaha untuk memeroleh kembali hak kesulungan. Dalam perspektif Suku Kambrauw, orang-orang yang berkuasa di Kaimana pada masa lalu, Raja Ombaiyer, dan sekarang Raja Komisi, ialah keturunan pendatang dari Geser dan Gorom yang menikah dengan orang-orang Mairasi.

Konflik perebutan batas tanah di Kaimana menurut Tohari dan Luthfi (2011) disebabkan oleh perkembangan Kecamatan Kaimana yang sekarang ini menjadi ibukota kabupaten, sehingga menarik cukup banyak investor. Berkaitan dengan pertentangan di antara suku-suku di Kaimana, seorang tokoh masyarakat pendatang dari Suku Buton, Lasaja, mempertanyakan mengapa mereka baru menggugat tanah di Kaimana pada masa sekarang, tetapi tidak menggugatnya pada masa Belanda dan awal kemerdekaan Indonesia? (Wawancara 15 Februari 2009). Mengapa tanah-tanah di Kaimana digugat setelah Kaimana telah dimekarkan menjadi kabupaten tetapi tidak digugat sewaktu masih menjadi distrik? Sepengetahuan dirinya pada tahun 1952, tuan tanah dari Kota Kaimana sampai Kampung Baru Coa hanyalah keluarga Lawai, yakni Moike Lawai, Kepala Kampung Kota Kaimana.

Waktu Lasaja ingin membeli tanah untuk berkebun di Tanjung Simora, ia datang ke Kapitan Abdul Manaf Watora yang mengepalai Kampung Baru Coa (Matua). Kapitan mengatakan: "Kau pi dulu ke Paitua Lawai di Krooy. Kalau beliau sudah setuju, kau tinggal kerja saja." Kemudian ia pergi lagi ke tokoh tua yang lain di Bantemin yakni Moyali Ufnia. Ia berkata: "Hei..Kau pi dulu ke Paitua Lawai, baru kau kerja setelah ia kasih tanah.” Pada akhirnya, Lasaja datang ke Moike Lawai, dan yang terakhir ini memberikan tanah untuk berkebun. Selain itu, Lasaja ingin membangun rumah di Jalan Cenderawasih, Kaimana. Ia pergi menghadap Raja Komisi Ahmad Aituarauw untuk membeli tanah. Raja Komisi berkata: "Hei..kau pi dulu ke Paitua Lawai di Krooy. Setelah dapat surat pelepasan tanah, baru kau dapat bangun rumah." Demikian juga pada saat mengurus ijin bangunan untuk rumah kepada bestuur Belanda. Beliau berkata, "Hai, kau perlu surat tertulis dari Paitua Laway dulu baru dapat bangun rumah." Akhirnya ia pergi ke Kepala Kampung Kaimana, Moike Lawai, untuk meminta permohonan pelepasan tanah. Cerita Lasaja ini menunjukkan bahwa secara faktual keluarga Lawai telah memiliki dan menguasai tanah di Kaimana sejak zaman Belanda sampai sekarang. Pengalaman Lasaja membuktikan bahwa Kaimana Kota merupakan pertuanan suku Koiwai (Silzer \& Heikinnen 1984, Widjojo 2009, Luthfi 2012). 


\section{Komunitas pendatang di Kaimana}

Kaimana ditempati oleh beragam suku baik orang asli Papua maupun pendatang. Upton (2009) menulis bahwa migrasi orang non-Papua ke Kaimana telah berlangsung sekitar seribu tahun yang lalu. Klaim atas hak pertuanan oleh suku-suku orang asli Papua mengusik hubungan antara orang asli Papua dengan kelompok suku pendatang di Kaimana yang nenek moyangnya sudah menetap di Kaimana sejak 1900an. Mereka datang ke Kaimana dengan keluarga mereka, dan membangun komunitas yang tinggal dalam lingkungan tertentu. Kemudian, lahirlah Kampung Seram, Kampung Cina, dan Kampung Buton.

Kedatangan orang-orang Buton di Kaimana diduga sebelum Belanda datang ke Kaimana pada akhir abad ke-19. Pada tahun 1942, salah seorang tokoh masyarakat Buton, La Abudani, menyaksikan bahwa wilayah yang sekarang ini dinamakan Krooy masih berupa hutan belantara ketika ia masih anak-anak (Wawancara 21 Desember 2008). Di atas tanah itu tinggal keluarga orang Buton yang menanam pohon kelapa bersama dengan Keluarga Lawai. Hubungan antara orang asli Papua dengan pendatang pada masa lalu ditandai dengan perdamaian dan toleransi antarkelompok etnik. Pada tahun 1966, dirinya mulai berdagang di Lobo tempat orang-orang suku Mairasi. Menurutnya, orang-orang Mairasi adalah salah satu suku asli Papua yang memiliki hubungan baik dengan pendatang. Pada hari raya Idul Fitri, orang-orang suku Mairasi datang bersilaturahmi ke rumah para pendatang, namun sesudah jatuhnya Orde Baru, keberadaan pendatang seolah-olah menjadi musuh bersama orang asli Papua. Hal tersebut disebabkan oleh pembangunan ekonomi pada masa Orde Baru yang telah memarjinalkan orang asli Papua (Widjojo, Satrio M, Amiruddin, Al Rahab, Pamungkas C \& Dewi R 2008). Selain itu, di Papua pada tahun 2000 muncul gerakan menuntut kemerdekaan Papua, terutama pembentukan Presidium Dewan Papua (PDP) sebagai protes terhadap pelanggaran HAM yang terjadi selama masa Orde Baru. Pendatang dianggap sebagai pendukung Pemerintah Indonesia yang merupakan musuh bersama aktivis Papua Merdeka.

Sumbangan masyarakat Buton terhadap perkembangan Kaimana melalui profesi nelayan yang melayani kebutuhan ikan masyarakat, dan bekerja sebagai petani dan pedagang. Orang Buton menanami kebun-kebun di sepanjang Pantai Kaimana dengan pisang dan kelapa. Pada tahun 1966 diperkirakan terdapat 40 KK yang bekerja di pesisir Pantai Kaimana. Pada tahun 1971 dirinya bertemu dengan Bupati Fak-fak, Sukamto, yang sedang berkunjung ke Kaimana dengan status sebagai Kepala Suku Sulawesi Tenggara. La Abudani meminta Bupati Fak-fak agar Kaimana diberikan listrik karena masyarakatnya telah berjasa dalam perjuangan integrasi Papua ke Indonesia, namun baru pada tahun 1982 listrik masuk ke Kaimana. Perkumpulan orang Buton memiliki anggota sekitar 800 KK di mana pada tahun 1966 hanya sekitar $40 \mathrm{KK}$. Tugas perkumpulan adalah membina kerukunan hidup antar-orang Buton, dan antara orang Buton dengan suku-suku non-Buton.

Selain orang Buton, orang dari suku-suku Sulawesi Selatan jumlahnya cukup besar di Kaimana. Nurdin Arsyad, Ketua KKSS (Kerukunan Keluarga Sulawesi Selatan) menjelaskan bahwa KKSS adalah suku yang wilayahnya bersifat nasional. Hal ini yang membedakan dengan suku-suku lainnya (Wawancara 25 Desember 2008). Setiap ada warga Sulsel di suatu tempat, maka secara otomatis muncul organisasi KKSS. Para tetua yang ada di wilayah itu juga secara otomatis menjadi pengurus KKSS. Musyawarah pertama KKSS di Kaimana diadakan pada tahun 1971 yang dihadiri oleh 30 peserta yang sebagian besar merupakan pedagang di Pasar Kaimana. Menurut Nurdin, KKSS beranggotakan $900 \mathrm{KK}$ atau 3.000 orang yang tersebar hampir di seluruh distrik saat ini. Sebagian besar dari mereka bekerja sebagai pedagang pakaian, makanan, dan petani. Beberapa kegiatan KKSS ialah membangun masjid di Pasar Baru; menyelenggarakan pengajian; mengadakan lomba seni; membuat pertandingan olah raga; dan membentuk Ikawan Wanita Sulawesi Selatan (IWSS).

Menurut Nurdin, sumbangan utama KKSS ialah menyangga perdagangan di Kaimana. Hampir di seluruh pasar tradisional dari kota sampai kampung terdapat pedagang dari Sulawesi Selatan yang berjualan pinang, pakaian, ikan serta komoditas lainnya. Pedagang Tionghoa hanya berjualan di kompleks Pertokoan Kota Kaimana, namun masalahnya adalah mereka mendominasi kapal tujuh 
kapal barang, sehingga orang KKSS dan KKST harus menyewa kapal-kapal tersebut dengan harga sewa yang tinggi untuk ekspedisi dari Surabaya ke Kaimana.

Pada dasarnya, orang asli Papua telah diberikan prioritas oleh Pemerintah Kabupaten Kaimana dalam wilayah ekonomi terutama pada pemilikan los-los di pasar yang dibangun oleh pemerintah. Nurdin menceritakan bahwa orang-orang asli Papua telah diberikan 30 los pada prosesi pembukaan Pasar Daerah Kabupaten Kaimana, namun tidak sampai enam bulan hampir semua los telah jatuh ke tangan orang Bugis karena orang-orang asli Papua menyewakannya, dan kemudian menjualnya kepada mereka. Hal tersebut karena orang asli Papua kurang mampu bersaing dalam kegiatan ekonomi. Orang asli Papua sudah diberikan kebijakan afirmasi dalam ranah ekonomi, namun mereka belum memiliki kualitas sumber daya manusia yang cukup, terutama kemampuan manajerial dalam aktivi perdagangan, untuk bersaing dengan pendatang.

Jumlah orang Jawa juga cukup banyak di Kaimana. Mereka bekerja sebagai guru dan pedagang makanan. Menurut Ketua IKKJ (Ikatan Kerukunan Keluarga Jawa), Wagiantoto, organisasi ini berdiri pada Oktober 1983. Para pendirinya adalah Danramil Kaimana Kapten Sogol, Undang Soleh (polisi), Husen Alwi (Sunda), Imam Suhada (Jatim) dan wakil masyarakat Madura yang beranggota sekitar 20 keluarga (Wawancara Wagiantoto 5 Januari 2009). Sekretariatnya pada waktu itu di Koramil Kaimana. Tugas IKKJ ialah mengoordinir kegiatan-kegiatan masyarakat Jawa seperti mengelola hajatan keluarga dan mengadakan syukuran bersama. Adapun jumlah anggotanya pada masa kini mencapai 2.000 orang.

Ia mengakui setiap ada permasalahan dengan orang asli Papua seperti pemalangan tanah atau klaim terhadap kepemilikan tanah, dirinya berkoordinasi dengan Polsek Kaimana dan Komandan Kompi di Kilometer 4 Kaimana khususnya mereka yang berasal dari Jawa untuk membantu menyelesaikannya, namun setiap konflik antara orang Jawa dengan orang Papua dapat diselesaikan melalui musyawarah dengan para ketua adat. Pada tahun 2007, masyarakat Pasundan yang tergabung dalam IKKJ yang terdiri dari kalangan guru, dokter, polisi, dan tentara memisahkan diri serta membentuk IKP (Ikatan Kerukunan Pasundan) karena jumlah mereka cukup banyak dan seringkali kepentingannya tidak diakomodasi dalam IKKJ (Wawancara H. Djaeni 27 Desember 2008).

Kota Kaimana sekarang ini juga merupakan tempat bagi komunitas orang-orang asli Papua dari daerah pedalaman yakni Irarutu, Kambarauw, dan Mairasi. Di satu sisi, menurut orang Koiwai, ketiga komunitas tersebut adalah pendatang di Kota Kaimana. Di sisi lain, konsep pendatang dalam artikel ini hanya merujuk pada berbagai suku yang berasal dari luar Papua karena unit analisisnya adalah masyarakat adat Kaimana, yang sesuai dengan UU No. 21/2001 adalah yang merupakan bagian dari ras Melanesia. Harun Sabuku mengakui bawa tugasnya sebagai kepala suku adalah mengurus dan mengatur masyarakat Irarutu di Kaimana. Kewajiban ia lainnya adalah menyatukan, memfasilitasi, dan menyampaikan masalah mereka kepada Pemerintah Kabupaten Kaimana agar suku Irarutu lebih diperhatikan. Sekarang ini anggota komunitas ini mencapai $100 \mathrm{KK}$. Ciri-ciri orang Irarutu terdapat pada nama marga seperti Werfete, Furu, Waita, Refideso, Bari, Sabuku, Kurima, Furimbe, Puarada, Farissa, Nimbawu, Durie, dan Murmana. Kebanyakan orang Irarutu bekerja sebagai pegawai negeri, imam, dan pada sektor jasa di Kota Kaimana. Komunitas lain yang jumlah anggotanya cukup signifikan adalah masyarakat Suku Kambrauw di Kaimana yang mencapai 300 KK. Ikatan kerukunan ini, yang dibentuk pada tahun 2008, bertugas untuk memberdayakan masyarakat adat Kambrauw yang menetap di Kota Kaimana. Selama ini, para pimpinan Suku Kambrauw seperti Agus Tumanat, Karel Meigi, dan David Aboda dikenal sebagai anggota Panel Dewan Papua yang bersifat kritis terhadap hak pertuanan yang dimiliki suku-suku pantai di Kota Kaimana. Selain Suku Kambrauw juga terdapat komunitas Suku Mairasi di Kota Kaimana yang dipimpin oleh Joshua Salipada. Orang Mairasi lebih banyak bekerja di kebun-kebun di sekitar Kota Kaimana.

Hubungan antara orang asli Papua dengan komunitas pendatang mengalami pasang surut tergantung dari situasi politik di Tanah Papua khususnya hubungan antara pemerintah dengan orang asli Papua. Sebagaimana telah dijelaskan di muka, ada dua momen politik yang berimplikasi pada memburuknya 
hubungan antara orang asli Papua dengan Kaimana. Pertama, menguatnya gerakan menuntut kemerdekaan orang Papua ketika reformasi tahun 1998. Kedua, pemekaran Kabupaten Kaimana yang sebelumnya merupakan bagian dari Kabupaten Fak-fak. Sebagai akibat dari pemekaran daerah, sukusuku asli Papua menuntut kembali hak pertuanan atas tanah di Kota Kaimana yang sekarang ini banyak ditempati oleh para pendatang. Berbagai wawancara dengan sejumlah tokoh pendatang dapat diketahui bahwa mereka tidak ingin mencampuri urusan hak pertuanan atas tanah di Kota Kaimana, namun mereka memiliki bukti bahwa tanah yang mereka tempati sebelum Kaimana menjadi bagian dari Indonesia sudah diberikan oleh orang-orang Koiwai, dan disahkan secara tertulis oleh Raja Komisi. Orang-orang Koiwai atau disebut dengan Kaimana pantai sejak masa Belanda secara de facto telah menguasai tanah di Kaimana. Dengan demikian, para pendatang mengklaim bahwa tanah mereka tidak dapat diganggu gugat oleh suku-suku orang asli Papua yang menuntut hak pertuanan.

Dewan Adat Kaimana yang terbentuk tahun 2009 merasa penting untuk mengidentifikasi batas-batas tanah masing-masing suku di Kaimana, namun belum ada program yang nyata dari Dewan Adat maupun Pemkab Kaimana untuk menetapkan tanah-tanah adat yang berimplikasi pada hak pertuanan hingga saat ini. Ketika pembangunan ekonomi semakin meningkat di Kota Kaimana, hal ini berimbas pada tuntutan ganti rugi oleh beberapa suku yang mengklaim bahwa tanah yang digunakan oleh pemerintah maupun investor merupakan tanah mereka (Luthfi 2012).

\section{Simpulan}

Berdasarkan uraian di muka dapat diketahui bahwa persoalan-persoalan dalam relasi-relasi sosial antara sesama orang Kaimana jauh lebih kompleks daripada antara orang Kaimana dengan para pendatang khususnya jika kita menggunakan kategori analitis dalam pembedaan masyarakat Kaimana. Di antara delapan suku besar di Kaimana, Suku Koiwai sejak masa Belanda dianggap sebagai suku yang dominan dalam ranah politik, dan pengaturan tanah ulayat di Kaimana. Keluarga Aituarauw yang menjadi Raja Komisi dan Raja Ombaiyer dari Namatota merupakan elit Suku Koiwai. Demikian juga para kepala pertuanan tanah di Kota Kaimana seperti keluarga Lawai, Simora, dan Sirua yang merupakan bagian utama dari Suku Koiwai. Hal ini menimbulkan kecumburuan di antara suku-suku lain yang sesudah pemekaran berusaha mempertanyakan legitimitas orang-orang Koiwai ini.

Hak kesulungan di Kaimana merupakan wacana sekaligus strategi yang dilemparkan oleh suku-suku di Kaimana yang selama ini merasa dipinggirkan dan sumber dayanya diambil oleh para pendatang. Jika diamati secara lebih mendalam, hak ini dapat dimaknai sebagai kebutuhan akan adanya pengakuan terhadap suku-suku tersebut. Persoalan yang penting tidak terletak pada siapakah orang Kaimana asli tetapi bagaimanakah cara yang tepat untuk memberikan rekognisi terhadap kelompokkelompok atau suku-suku yang selama ini tertinggal dalam proses pembangunan sumber daya manusia di Kaimana.

Dimensi yang tidak kalah pentingnya adalah relasi sosial antara orang Kaimana dengan para pendatang. Relasi sosial antara pendatang dengan orang-orang Kaimana juga dipengaruhi oleh perbedaan agama. Orang-orang Kaimana yang beragama Islam merasa memiliki hubungan yang lebih dekat dengan para pendatang yang beragama Islam walaupun hal ini tidak berlaku secara umum. Orang-orang Koiwai atau suku pantai yang telah beragama Islam jauh sebelum kedatangan Belanda memiliki tradisi yang lebih terbuka dengan dunia luar sehingga tidak mempersoalkan kembali akan keberadaan pendatang. Mereka yang mempersoalkan pendatang cenderung datang dari suku-suku yang selama ini merasa dimarjinalkan dalam pembangunan.

Implikasi teori dari studi ini adalah batas-batas sosial antara suku Koiwai dengan suku-suku lain yang juga merupakan orang asli Papua berubah dari masa ke masa. Sebelum reformasi 1998, identitas penanda yang menjadi ciri dari batas-batas sosial dibentuk melalui pembagian kerja. Orang Koiwai kebanyakan bekerja sebagai nelayan dan menetap di pantai Kota Kaimana sedangkan orang Mairasi, Irarutu dan suku-suku lain kebanyakan bekerja sebagai petani atau berburu, dan menetap di daerah perdalaman. Setelah reformasi 1998 terutama setelah pembentukan Kabupaten Kaimana tahun 2002, batas-batas sosial tersebut dipertanyakan secara masif. 


\section{Daftar Pustaka}

Barth F (1988) Kelompok etnik dan batasannya. Judul asli Ethnic Group in Boundaries, diterjemahkan ke dalam Bahasa Indonesia oleh Nining I. Susilo. Jakarta: Universitas Indonesia Press.

Berger P \& Luckman T (1979) Introduction dalam The social construction of reality. New York: Penguin Books.

Aass S (1984) Relevansi teori makro chayanov untuk kasus Pulau Jawa. Dalam Tjondronegoro, SMP \& Wiradi G (ed). Dua Abad Penguasaan Tanah: Pola Penguasaan Tanah dari Masa ke Masa. Jakarta: Gramedia.

Dewan Adat Kaimana (2010) Tata ruang wilayah adat Kaimana. Tidak dipublikasikan.

Durkheim E (1984) The division of labour in Society, diterjemahkan oleh W.D. Halls pengantar dari Lewis A. Coser. New York: The Free Press, A Division of Macmillan Inc.

Downman, SA (2004) Intra-ethnic conflict and the Hmong in Australia and Thailand. Desertasi pada Department of International Business and Asian Studies, Griffith University, 22 Oktober 2004. [Diakses 25 September 2007]. www.gu.edu.au.

Hall S (1999) Cultural identity and diaspora. Dalam: Kathryn Woodward dkk. Identity and Diaspora. London: SAGE Publication.

Iribaram A (2011) Satu tungku tiga atu: Hubungan tiga agama di teluk Patipi Fak-fak. Etnohistori edisi khusus Papua.

Kellas JG (1998) The politics of nationalism and ethnicity. London: MCMILLAN Press.

Locke J (1924) Two treaties of civil government. London: Dent \& Sons Ltd.

Luthfi AN (2012) Pala, otsus, dan kerentanan identitas di Kaimana. Ethnohistory edisi 15 Maret.

Marx K (1844/2012) Economic and philosophic manuscripts of 1844. Courier Dover Publications.

Rex J (1985) Hubungan ras dalam teori sosiologi. Diterjemahkan ke dalam Bahasa Melayu oleh A. Nazri Abdullah, MA dari Race Relation in Sociological Theory. Kuala Lumpur: Dewan Bahasa dan Pustaka Kementrian Pelajaran Malaysia.

Silzer PJ \& Heikkinen H (1984) Index of Irian Jaya languages. Jayapura: Program kerjasama Universitas Cenderawasih dan Summer Institute of Linguistics

Suharsiningsih (2009) Tanah terlantar: Asas dan pembaharuan konsep menuju penertiban. Jakarta: Prestasi Pustaka.

Soehardi A (1979) Pengantar hukum adat Indonesia. Bandung: Sumur.

Tohari A \& Luthfi AN (2011) Laporan dokumen sejarah kampung Kaimana. Paper untuk Partnership for Governance Reform Jakarta dan Centre for LEAD Yogyakarta. Tdak dipublikasikan.

Upton S (2009) The impact of migration on the people of Papua, Indonesia. Disertasi, University of New South Wales.

Van Peursen CA \& Hartoko D (1976) Strategi kebudayaan. Penerbitan Kanisius.

Weber M (1978) Economy and society. Berkeley: University of California Press.

Widjojo, Satrio M, Amiruddin, Al Rahab, Pamungkas C \& Dewi R (2008) Papua road map. Jakarta: Indonesian Institute of Sciences.

Widjojo MS (2009) Aspirasi dan kegelisahan masyarakat adat. [Diakses 27 Juni 2015]. http://www.aldp-papua.com/aspirasi-dan-kegelisahan-masyarakat-adat-di-kaimana/.

Widjojo, Muridan, \& Rusdiyarti SR (2014) Kaimana di Masa Lampau. Dalam: SR Rusdiyarti (ed). Sejarah Masyarakt dan Pemerintahan Kaimana, monografi hasil penelitian tim sejarah Kaimana LIPI. Tidak diterbitkan.

https://www.google.com/search?q=kota+kaimana\&biw=1600\&bih=755\&source=1nms\&tbm= isch\&sa=X\&sqi=2\&ved=0CAcQ_AUoAmoVChMIwLSDxfOqyAIVz56OCh3TWQBc\&dpr=1\#tbm= isch\&q=kaimana\&imgrc $=$ TuPmfaLqOstwM\%3A 